Khmiliar O. F., Doctor of Psychological Sciences, Associate Professor, Head of the Department of Social Sciences of Ivan Chernyakhovsky National Defense University, Kyiv, Ukraine https://orcid.org/0000-0003-2693-1906

\title{
THE DIAGNOSTICS AND CORRECTION OF THE MENTAL STATES OF THE SERVICEMAN, WHO ARE EXPERIENCING PHANTOM PAINS
}

\begin{abstract}
В статті досліджено особливості протікання психічних станів військовослужбовиів - учасників бойових дій, які переживають фантомну біль. Охарактеризовано наслідки перебування військовослужбовия в бойових умовах. Розкрито проблеми, з якими зіштовхуються учасники бойових дій після повернення із зони ведення бойових дій.

Сформовано дві групи досліджуваних осіб. До першої увійшли пащієнти, які отримали поранення в під час ведення антитерористичної операції без ампутації кінцівок. Другу склали поранені з травматичними ампутаціями кінцівок. З'ясовано, щяо психічний стан військовослужбовия, який переніс травматичну ампутацію кінцівки ототожнюється зі станом гострого горя. Факт ампутаиії пережсивається як важка особиста трагедія, ще має величезний руйнівний сенс. Ампутація призводить до краху всіх життєвих перспектив і планів військовослужбовия, що проявляється у переоцінці власного «Я», істотному зниженні рівня домагань, необхідності пошуку соџіальної ніші й часто у втраті сенсу життя.

Характерними для стану поранених обох груп є високі показники реактивної тривожності. Встановлено типові механізми психологічного захисту, спрямованого, на усунення тривоги. Основними варіантами психологічного захисту для поранених військовослужбовців $\epsilon$ агресія, раціоналізація, регрес в інфантильній фазі з властивими їй імпунітивним способом реагування.

Окреслено ключові напрями психотерапії в роботі з військовослужбовиями, наведено приклади прийомів дзеркальної терапї для подолання фантомних болів. Показано ефективність дзеркальної терапії для військовослужбовия з ампутованою кіниівкою завдяки зоровому зворотному зв'язку.
\end{abstract}

Ключові слова: психічний стан; фантомна біль; стресс; психічна травма; дзеркальна терапія.

Introduction. Staying in the zone of ATO is an extreme situation, when a person constantly experiences strong stress and overcomes it by means of his volitional efforts. It has a very negative effect on mental health - almost all the combatants in Ukraine inevitably undergo some changes in physical and mental health.

The statistics show that every fifth serviceman, who has no physical damage, and every third injured and mutilated serviceman suffers from neuropsychiatric disorders. Other consequences, such as psychosomatic illness, start in a few months after returning to the normal life. According to the experts from the Military Medical Academy, the combatants (in comparison with healthy people) have a two to three times higher probability of diseases such as hypertension, gastritis, peptic ulcer of the stomach and duodenum ("The actual problems of the psyhological help, social and medicopsyhological rehabilitatiom of the partakers of ATO", 2016; Os`odlo \& Khmiliar, 2012). They may also experience weakness, dizziness, decreased ability to work, headaches, pain in the heart, sexual disorders, insomnia, phobias, fears, etc.
The main problems, that former soldiers are facing, comprise fear (57\%), demonstrative behaviour $(50 \%)$, aggressiveness $(58.5 \%)$ and suspicion $(75,5 \%)$. Their behavioural features include conflicts in the family, with colleagues at work, outbreaks of anger, alcohol and drug abuse (Khmiliar, Krasnytska \& Os'odlo, 2017). In addition, this mental disorder leads people to suicide, peculiar types of aggression, fear of attack from the back, feeling of guilt for staying alive, perception of oneself as dead. For the partakers of the ATO, emotional tension and isolation, increased irritability and aggressiveness, noncausal outbursts of anger, fear and anxiety attacks are also characteristic. However, all these difficulties might even become more serious, if a person has his limb amputated. Such individuals need special psychological help and support.

The revealed features should be taken into consideration when organising rehabilitative activities for the partakers of the anti-terrorist operation. Special attention should be paid to the need for psychosocial work with them. Medico-psychological rehabilitation, psychological help and social support should be 


\section{Питання психології}

the main directions of work with this category of people.

Analysis of the Research into this Problem. Getting injuries or amputations during hostilities is a serious psycho-traumatic factor that specifically affects a person, largely defining the features of psychological assistance in the process of socio-psychological adaptation after returning to a peaceful life. This problem becomes particularly acute because of the emergence of a large number of disabled people with the defects of limb amputations that are left after hostilities. Among the sanitary losses in wars, injuries of the limbs are nowadays the most common (from 52 to $67 \%$ ). $6-8 \%$ of the cases are accompanied by traumatic amputation, or surgeons are forced to perform amputation during surgeries. An enormous problem is the anti-personnel mines, stretch marks left after hostilities, on which the civilians explode. Such injuries are not always statistically accounted, however, they are quite common.

The mental state of the person, who has undergone traumatic amputation of the limbs, can be classified as acute grief, which recently received much attention by military psychologists. The fact of amputation is experienced as a personal tragedy, which has a huge destructive meaning. Amputation means for an individual a collapse of all of the life prospects and plans, a reappraisal of his own "Self", a significant reduction in the level of aspirations, the need to find a social niche and often a loss of the life meaning. Whatever the level of psychological preparation for such a scenario (e.g. people of dangerous occupations - rescuers, servicemen) was, amputation is still perceived as a personal disaster (Khmiliar, Os'odlo \& Krasnyts'ka, 2017; Korolchuk, Korolchuk \& Kulazhenko, 2014). This is pronounced by cases of suicidal attempts immediately after the injury, when awareness of the loss of the limb occurs. Such situations require allo- and intrapsychic adaptation, long mental work, and the ability to overcome the grief.

The aim of the article is to illustrate the specificities of the psychological help for the injured servicemen experiencing phantom pains.

The Statement of the main Research Material. "The Work of Grief," the peculiarities of personal recovery during the severe physical trauma have been systematically and comprehensively studied since the Second World War (Hmilar, 2016). As a result, the research has identified the factors that determine an individual reaction to severe physical trauma. Filling a person's life in the post-traumatic period with a new meaning, setting vital goals contributes to solving the main problems that arise after injury. Often the problems include socially inappropriate attempts of compensation - the usage of alcohol, drugs, commitment of suicide.

It should be stated, that, unlike civilians, soldiers injured in the ATO suffer from double burden - physical deterioration and participation in hostilities.

The example of this is 34 years old Viktor, who served in reconnaissance. In August 2014, he was captured by terrorists. At the time of psychological counseling he was undergoing a psychological rehabilitation in the medical center. He was dreaming of returning to his military base as soon as possible.

The extract from a conversation with a psychologist.

Victor (V): (with a hidden smile). Different feelings are overwhelming me. I do not even know what I'm doing here. During the last few months, someone else is managing my life, almost nothing depends on me.

Psychologist (P): Maybe there are feelings on which you would like to concentrate?

V.: There are a lot of them. You see, I'm a simple car mechanic, but I was forced to join the army. I had to fight. But, do not think of anything bad (Pause). In battle or in reconnaissance, I was very determined. Although I am usually kind, even a little shy, I showed all my fury and hatred.

P.: All people are shy. You must be able to suppress this feeling, but do not lose it. Not even during the war.

V.: I never lose my heart. Reconnaissance servicemen are responsible for the entire unit. However, we are not all-powerful too.

P.: What do you mean saying "not allpowerful"?

V.: Our task is not just to gather information about terrorists, not exposing ourselves, but also to ensure the future success of the task. Terrorists hunt for us too. On August 4, our machine exploded. Two of us died, and three were taken to prison. We have only recently been exchanged. They saw the trident on my arm and I was subjected to constant torture. The reconnaissance serviceman does not have to expose himself. Why did I make that tattoo?!

P.: How long have you been in prison?

V.: 32 days. Although each day seemed to be a year. At first, we were kept in a sewer hall 


\section{Питання психології}

near the water tower. On the fifth day, they moved us to Donetsk. We were also kept in a warehouse, which they closed with a hatch from the top.

P.: Did you hope, that you would ever get the chance to get out of that hell?

V.: That feeling came to me on the third day. If they hadn't killed me yet, then, they don't have the desire to do that at all. Later on, they opened the hatch every night and threw a grenade. In 7 days 16 grenades were thrown. Four firecrackers and 12 simple billets. They wanted to scare us all the time...

P.: It must have been hard to experience that.

V.: Yes, it wasn't easy. But it was even harder to endure the parade of humiliation of our dignity on August 24, in Donetsk. As I was walking, I suddenly started thinking whether those people needed my protection. I saw a girl aged five or six, who was trampling our flag, and her mother, satisfied with the actions of her kid. It's not right at all. Or another time. We have been involved in military activities and walked through villages. Locals used to come out to bless us and wave their hands. However, there was always one person, who "showed the middle finger" and you would be in a bad mood. Therefore, you start thinking again, whom you had been protecting [3].

There are a lot of reasons to believe that the psycho-traumatic factors will have a mutually suppressive effect on the individual. The previous experience has shown that special attention in the treatment of such injured people should be paid not only to the range of issues related to healing the wound and subsequent prosthetics, but also to the implementation of comprehensive programs of medical and psychological rehabilitation. Such an approach has begun to be successfully carried out in a number of central hospitals. However, a very special situation of people, who have suffered from the traumatic limb amputation during the conduction of hostilities, demand some refinements of standard procedures.

\section{research.}

Organisation and methods of the

To achieve the goals of the work, a special study was conducted in which psychological characteristics of the injured, who undergo rehabilitation at the Central Military Clinical Hospital, were studied. We tested 45 men aged 21 - 36 years with different military ranks, fixed-term and contractual service. All patients suffered from traumatic injuries of the different severity and were admitted to the hospital averagely 2 months after the injury.

The injured were divided into two groups. The first included patients who were injured in the zone of anti-terrorist operation and had no amputations (usually, gunshot wounds of the limbs) (21 people). The second included the injured with traumatic limb amputations (24 people). The control group (20 people) consisted of university students aged $19-24$ years (average age corresponded to the age in experimental groups).

The injured went through a comprehensive clinical and psychological examination that included: a clinical conversation conducted according to the type of the structured interview, Minnesota Multiphasic Personality Inventory (MMPI), an associative experiment carried out using the "prolonged response" method. To clarify the diagnoses, an additional set of techniques was used: projective techniques "Non-existent Animal", the test of Rosenzweig and Luscher; verbal methods of personal and situational anxiety of Charles D. Spielberger and Yu. L. Hanin, a subjective assessment of well-being, activity, mood (WAM) (Raygorodskyi, 2002).

Our associative experiment was aimed at identifying the semantic core of a person. Nowadays, many of its modifications are used. It is one of the most advanced methods of semantic analysis (Khmiliar, Os'odlo \& Krasnytska, 2017). Various psychological and psycholinguistic tasks are solved with it, for example, the study of individual differences, processes of thinking, the formation of language in ontogenesis, semantic fields. In our opinion, the ability to reflect specific features of life in them, the actual state of the subject, his life experience, as well as the views and assessments of the future is an important characteristic of associations. In the associative experiment, we used the following keywords: home, life, happiness, future, war. This choice was based on the experience of a similar survey conducted after the civil war on the Balkans.

Subsequently, the results of the survey were used to clarify the directions of psychocorrectional and psychotherapeutic work.

The interpretation of the obtained results made it possible to detect some signs of a stress disorder in the participants of the experiment. They included re-experienced injury and trauma, sleep disturbances (nightmares, difficulties in sleeping or disturbances in the duration of sleep), changes in the behaviour, 


\section{Питання психології}

irritability, or outbursts of anger, alcohol abuse, in order to get rid of painful experiences, memories or feelings, depression.

The symptoms of a stress disorder were noticed in $37 \%$ of injured and $23 \%$ of amputees, but they were different in both groups. Stress disorders are often predetermined by sleep disorders, manifested by difficulties of falling asleep, haunting nightmares with vivid pictures of the traumatised events. These phenomena were substantially absent among the injured with limb amputations (2-3 months after injury), but for cases, when phantom pains occurred during sleeping.

As a rule, the content of the victims' dreams is of a completely peaceful nature. "Amputees" dream to be healthy, seeing themselves in the process playing; locomotor acts that have a special emotional saturation are necessarily present - they walk in the fresh morning dew, run along the way, and so on. As a rule, the meaning of dreams of the injured without amputation reflected the traumatic experience associated with the moment of injury.

The characteristic feature of both groups of the injured was a high level of state anxiety. Therefore, particularly interesting is the identification of the typical mechanisms of the psychological protection, directed, as it is known, to eliminate anxiety.

The main variants of the psychological protection of the injured were aggression, rationalisation, regression in the infantile phase with the impulsive response ("escape from the situation"), and the refusal to actively overcome stress. Almost all of the injured had explicitly expressed aggression in relation to someone who, in their opinion, caused their misfortune. For example, these could have been commanders who, without an artillery training, threw a unit into battle, or comrades who did not cover the withdrawal of a special forces group. One soldier with amputations of both legs after two months of treatment was confident that one of his legs was amputated by mistake. This aggression was a way out of unmotivated rudeness in relation to the staff. Such patients, as a rule, rarely had signs of intrapsychiatric adjustment that would allow them to adapt to new conditions of life. This group was characterised by the presence of images of aggressive reactions in the drawings (according to the method of "Non-existent animal").
Rationalisation is the second most frequent mechanism of psychological protection. There were often cases when the injured did not tell their relatives about the actual state, hoping to talk about an injury during a personal meeting, taking care of their relatives, their adequate response to the situation. A characteristic feature of such people is the construction of an explanatory system for the event that occurred, the conceptualisation of the cause of the injury. The victims form a system of explanations, of why the accident happened to them, and not to someone else. In some cases, the soldier was sure that even his presence in the anti-terrorist operation zone would make him disabled.

Thus, aggression carries out a protective and adaptive function to a certain moment, blocking for some time the stressful symptoms. However, the strategy of protection against stress is initially unconstructive. From the standpoint of the psychodynamic approach, the addictive behaviour that occurs under the influence of stress can be regarded as a regression in the infantile phase with a failure to overcome difficulties. This assumption is confirmed by the data of the Rosenzweig drawing frustration test, where the partakers of the experiment showed more "visible", in comparison with the control group of students, intrusive and protective responses to stimulating material.

This detail may further seriously impede the social rehabilitation of this group of the injured. Since in addition to the stressful action of the combat the injured are also experiencing stress associated with injury itself, the probability of an addictive behaviour of the injured increases in the peacetime. The research has shown that, rationalisation is the most favorable protective mechanism in terms of presupposing the success of further adaptation.

The MMPI profiles of the injured were significantly different from the control group. More than $50 \%$ of the surveyed had the same profile, characterised by elevated scores in the 2nd scale (depression), 4th (impulsiveness) and 9th (optimistic) and significantly lower scores in 0th (social introversion). A simultaneous increase in the 2nd and 4th scales leads to an internal conflict, in which different trends are emerging - high levels of harassment with uncertainty in themselves, high activity and rapid exhaustion.

In general, we have not found patterns of increasing on Depression scale, that could be connected with the specificity of the injury. The 


\section{Питання психології}

leading peak on the 9th scale in the profile of the injured shows a high level of optimism, liveliness and activity, initiative, the desire to be in the society, talkativeness. Excessive selfesteem, easiness in decision-making, lenient attitude to their disadvantages - this is all due to the young age of the surveyed and is a variant of the youth norm. High scores on the 9th scale and low scores on the 0th scale may indicate a desire to get out of a traumatic situation through social contacts and social activity, that weaken the situation's effect.

The analysis of time and content of the associative experiment showed significant differences in the language effect on the keywords of the experimental and control groups.

The associations for the word "war" in the group of the injured and "amputees" differed significantly from responses to other keywords with high linguistic productivity and a short latent period, high emotional saturation (negative). We have identified 11 most commonly used responses to this word: death, dirt, blood, tears, grief, murder, friendship, weapons, betrayal, shooting, "hail" (BM-21 Grad rockets).

The responses of the injured to the keywords (life, happiness, future) were characterised by a long latent period and low productivity. The verbal activity of the injured is lower than that of the test group. At the same time, a large percentage (54\%) of nonproductive associations was observed in the injured (mostly there was a replacement of an adequate word by a phrase or a stereotyped statement). The analysis of time and content of the linguistic products indicates a serious change in the semantic core of the serviceman, combat activities, that is a characteristic feature of the surveyed, who were injured. The main content of the changes generally includes a loss of life prospects, disappointment, destruction of the semantic core of the person. The revealed peculiarities were mainly characteristic of "amputees". Patients are confused, they poorly imagine what to do and how to live after the excerpt from the hospital.

As we mentioned above, injury during the combat activities leads to serious changes in the personality of the soldier, which can include the formation of a symptom complex of PTSD, a specific profile of the person, obtained by the method of MMPI, characterized by an elevated scores on the 2nd, 4th and 9th scales, and decreased scores on the 0th scale. "Amputees" in comparison with other categories of the injured, are more emotionally stable (emotions are a part of the symptoms of PTSD). That is in our opinion due to a kind of "redemption" of guilt for the lost limb. In the same category of injured, greater destruction of the semantic core of the person was noted, which shows the necessity of conducting logotherapy along with the traditional psychotherapeutic procedures (Frankl, 2001).

Psychological help for the injured servicemen experiencing phantom pains. Our results enable us to assume, that the injured servicemen with limb amputations have a complicated nature of the origin of the phantom pains. In the aetiopathogenesis of phantom pain, the whole complex of psychological factors must be taken into consideration: violation of the intergenerational interaction, violation of the body's scheme, etc. This is evidenced, for example, by facts such as the different frequency of phantom pains on the right and left extremities. According to P. Halligan, "pain hallucinosis" - the phantom pain after amputation - appears in $66 \%$ of cases on leftside and 34\% right-side amputations (under other comparable conditions) (Halligan, 2002).

The unevenness of the frequency of the manifestations of the phantom syndrome is caused by the functional asymmetry of the brain, based on the sensory "specialisation" of the right and left hemispheres. The dominant hemisphere (left - right) is responsible for processing the symbolic (verbal-logical or linguistic) information. The subdominant hemisphere (right - left hand) is responsible for receiving and processing of the figurative, emotional signals. Pain impulses, which have an extremely high emotional saturation, are mostly "remembered" by the subdominant hemisphere, which causes a large frequency of phantom syndrome on the left half of the body (if the person is right-handed).

The observations prove, that cortical sections of various analysers complexly contribute to the origin of phantom pains. The mechanisms of pain development are more likely to be based on the complex interactions between interanalysers, activation of the old sensory enzymes. This proves the importance of the psychotherapeutic influence on the human psychics, that is suffering from phantom pain by teaching survivors the methods of autosuggestive action, harmonisation of the intergenerational interaction. 


\section{Питання психології}

The data of psychological testing became the basis for the development of individual and group psycho-correctional programs. The main element of it is considered to be logotherapy (by Frankl), aimed at overcoming the life crisis, finding new senses of life. The anti-crisis psychotherapy was taken as the basis. The second important direction of psychocorrectional programs, dedicated to the injured and amputees, is the formation of the ability to manage their conditions in order to remove the symptoms of anxiety and depression, reduce the intensity and prevent the phantom-pain syndrome. For this purpose the set if imaginary techniques and auto-training (in various modifications, for example, psychosomatic selfregulation) was successfully applied. At later stages of hospital rehabilitation, it is recommended to use behavioural psychotherapy in order to deal with the secondary potential traumatic situations, which an injured person may face after return to a peaceful life (e.g., interpersonal interactions, difficulties of professional self-determination).

An important component of psychological rehabilitation at the hospital stage is the implementation of various educational programs that show the injured the life perspective. Thus, it is worth mentioning that the Military Commissions should do everything to keep the servicemen, who had their limbs amputated, in the Armed Forces.

For example, there is an interesting US experience, where in the period of 8 years (1980-1988) 469 soldiers, who lost their limbs (usually not in the hostilities), were inspected. Only $11(2.3 \%)$ of them returned to Military service. All others have found it expedient to live on social assistance and social benefits.

The participation in the hostilities is itself a factor that goes beyond the ordinary human experience, which violates social adaptation. This forces the governments of the developed countries to pay special attention to the implementation of the assistance programs for the war invalids. Such program was successfully implemented in Israel, which allowed $28 \%$ of amputees return to the previous place of employment. Among the American veterans of two World Wars, 78\% returned to work or received higher education (Workbook for the post-traumatic stress disorder selfmanagement program (PTSD) for servicemen, 2015).

In our country, this problem is still far from the solution, especially in small towns and rural areas, where most of the soldiers, sent to fight in the ATO zone, live. Various studies on this issue, especially from the medical, psychological and social perspectives, will help to provide a decent life to people, who were injured in the hostilities.

Conclusions and perspectives of the further research work. The participation in hostilities negatively affects the mental health of a person, causing neuropsychiatric disorders, and often causes physical damage. The most influential negative traumatic factor for a serviceman is an amputation of the limb, because it means the collapse of all his life prospects and plans, the reappraisal of himself, a significant reduction in the level of aspirations, the need to find a new social niche and often the loss of meaning in life. In fact, stress disorder might cause other injuries.

Injuries during the hostilities result in the formation of PTSD and a specific personality profile, and the amputation of the limbs causes the destruction of the semantic core of the person. Amputees often experience phantom pains.

The basis of the psychological help for the injured experiencing phantom pains is the development of the individual and group psycho-correction programs. The main component of these programs is Frankl's logotherapy, aimed at overcoming the life crisis, finding the new meaning of life, and later stage-cognitive-behavioral therapy.

An important component of psychological rehabilitation at the hospital stage is the implementation of various educational programs that show the injured soldier life perspectives.

The prospects for the further research work are the development of the programs for social and psychological rehabilitation of the injured soldiers - participants of the hostilities.

\section{References}

1. Frankl V. (2001). Theory and therapy of neurosis. Preliminaries to logotherapy and existential analysis (pp. 55-59).

2. Halligan P. (2002). Phantom limbs: The body in mind. Cognitive Neuropsychiatry (7th ed., pp. 251-269).

3. Khmiliar O. (2016). Post-traumatic stress disorder: features of diagnosis and its signs in the participants of ATO. The Technologies Of The Development Of The Intelect, 2(3), 18. 


\section{Питання психології}

4. Khmiliar O., Os'odlo V., Krasnytska O. (2017). Military-psychological workbook for an officer (p. 93). Kyiv: Ivan Chernyakhovsky National Defence University of Ukraine.

5. Khmiliar O., Os'odlo V., Krasnyts'ka O. (2017). Military-psychological practical book for the officer (p. 91). Kyiv: Ivan Chernyakhovsky National Defence University of Ukraine.

6. Korolchuk M., Korolchuk V., \& Kulazhenko A. (2014). Psychological peculiarities of the long-term effects of stress: monograph (p. 276). Kyiv National University of Trade and Economics.

7. Os`odlo V., \& Khmiliar O. (2012). Military Psychology and Pedagogy: Innovative Approach (1st ed., p. 472). Kyiv: Ivan Chernyakhovsky National Defence University of Ukraine.

8. Raygorodskyi D. (2002). Practical psychodiagnostics. Methods and tests. (p. 672). Samara: "Bahram-m".

9. The actual problems of the psyhological help, social and medico-psyhological rehabilitatiom of the partakers of ATO. (2016). In the Interdepartmental scientific-practical conference. Kyiv.

10. Workbook for the post-traumatic stress disorder self-management program (PTSD) for military. (2015). (p. 49). Odessa.

\section{Резюме}

Хмиляр О. Ф., доктор психологических наук, доцент, начальник кафедры общественных наук НУОУ имени Ивана Черняховского

\section{ДИАГНОСТИКА И КОРРЕКЦИЯ ПСИХИЧЕСКИХ СОСТОЯНИЙ ВОЕННОСЛУЖАЩИХ, ПЕРЕЖИВАЮТ ФАНТОМНУЮ БОЛЬ}

В статье исследованы особенности протекания психических состояний военнослужащих участников боевых действий, которые переживают фантомную боль. Охарактеризованы последствия пребывания военнослужащего в боевых условиях. Раскрыты проблемы, с которыми сталкиваются участники боевых действий после возвращения из зоны ведения боевых действий.

Сформированы две группы испытуемых. В первую вочли пачиенты, которые получили ранения в ходе ведения антитеррористической операчии без ампутации конечностей. Вторую составили раненые из травматической ампутацией конечностей. Характерными для состояния раненых обеих групп есть высокие показатели реактивной тревожности. Установлены типовые механизмы психологической защиты, направленной на устранение тревоги. Основными вариантами психологической защиты для раненых военнослужащих есть агрессия, раџионализащия, регресс в инфантильной фазе с присущими ей импунитивным способом реагирования.

Определены ключевые направления психотерапии в работе с военнослужащими, приведены примеры приемов зеркальной терапии для преодоления фантомных болей. Показана эффективность зеркальной терапии для военнослужащего с ампутированной конечностью благодаря зрительной обратной связи.

Ключевые слова: психическое состояние; фантомная боль; стресс; психическая травма; зеркальная терапия.

\section{Summary}

Khmiliar O. F., Doctor of Psychology, Associate Professor, Head of the Department of Social Sciences, Ivan Chernyakhovsky

National Defense University of Ukraine

THE DIAGNOSTICS AND CORRECTION OF THE MENTAL STATES OF THE SERVICEMEN, WHO ARE EXPERIENCING PHANTOM PAIN

The article investigates the peculiarities of the mental states of military servicemen, participants of hostilities who are experiencing phantom pain. The consequences of being a soldier in combat conditions were described. The problems faced by the soldiers upon their return from the military zone were identified.

Two groups of subjects were formed. The first group included patients who were injured during an antiterrorist operation, but did not have any limb amputations. The second group comprised those patients, who were injured and experienced traumatic limb amputations. It was found out that the mental state of a serviceman who has experienced a traumatic limb amputation coincides with a state of acute grief. The fact of amputation is perceived as a grievous personal tragedy that has enormous destructive influence. Amputation leads to the collapse of all life prospects and plans of the serviceman, that is manifested in the reassessment of one's "I", a significant reduction in the level of harassment, the need to find a social niche and often in the loss of the life meaning.

The characteristic features of the condition of the injured in both groups are high rates of reactive anxiety. Typical mechanisms of psychological protection aimed at eliminating anxiety were defined. The main options of psychological protection of the injured servicemen are aggression, rationalization, regression in the infantile phase with the inherent impunitive response.

Key areas of psychotherapy, concerning the work with military personnel were outlined, examples of the methods of mirror therapy, used to overcome phantom pain, were given. The effectiveness of mirror therapy for an amputee soldier was proved through the visual feedback.

Keywords: mental state, phantom pain, stress, mental trauma, mirror therapy. 